\title{
Optimasi Formula dan Teknik Pembuatan Sampo Susu Sapi Segar Menggunakan Kombinasi Surfactant dan Co-Surfactant
}

\author{
Tika Emmawati ${ }^{*}$, Bambang Sidharta**, Oktavia Eka Puspita*** ${ }^{* *}$ Meyke Herina Syafitri ${ }^{* * * *}$
}

\begin{abstract}
ABSTRAK
Sampo yang baik dapat membersihkan dan memiliki emulsi minyak dalam air yang stabil. Variasi konsentrasi kombinasi surfactant dan co-surfactant, serta variasi penggunaan pelarut selama proses pengembangan dibutuhkan untuk mencari kombinasi yang paling ideal. Penelitian ini bertujuan untuk memperoleh formula dan teknik pembuatan sampo susu sapi segar yang optimum. Penelitian ini menggunakan desain penelitian eksperimental dengan menggunakan rancangan penelitian factorial design. Seluruh rancangan formula (F1-F9) yang menjadi sampel dalam penelitian ini, dibuat dengan konsentrasi kombinasi surfactant (sodium lauryl sulphate) dan co-surfactant (cocamide diethanolamide) yang bervariasi. Sampo dibuat dengan menggunakan pelarut yang berbeda yaitu metode $\mathrm{A}$ (aquades) dan $\mathrm{B}$ (aquades dan $\mathrm{NaCl}$ ). Setiap metode diaplikasikan untuk membuat sembilan formula (F1-F9). Replikasi sampel dilakukan sebanyak tiga kali. Pengamatan terhadap kualitas dan akseptabilitas sampo dilakukan selama 60 hari. Variabel yang diukur dalam penelitian ini adalah parameter sampo. Hasil dari penelitian ini menunjukkan bahwa evaluasi tahap satu terhadap stabilitas fisik dan $\mathrm{pH}$ sampo menghasilkan formula sampo 3B sebagai formula dan teknik pembuatan yang optimum. Emulsi formula $3 \mathrm{~B}$ paling stabil diantara seluruh formula, dengan nilai $\mathrm{pH} 6$,2. Formula sampo $3 \mathrm{~B}$ memiliki kemampuan mendispersikan kotoran ke dalam air dan kemampuan membersihkan $44,7 \%$. Busa yang dihasilkan memiliki tekstur lembut. Formula sampo 3B memiliki kandungan protein $0,4 \%$, nilai viskositas $670 \mathrm{Cp}$, dan tidak mengandung jamur serta bakteri patogen. Kesimpulan dari penelitian ini adalah formula $3 \mathrm{~B}$ merupakan formula optimum sampo susu sapi segar, yang menggunakan kombinasi surfactant $30 \%$ dan co-surfactant $1 \%$, yang dibuat dengan teknik pembuatan menggunakan metode $\mathrm{B}$ dengan pelarut berupa larutan $\mathrm{NaCl}$.
\end{abstract}

Kata kunci: Co-surfactant, Kualitas sampo, Sampo susu sapi segar, Surfactant, Teknik pembuatan.

\section{Optimization of Formula and Preparation Method of Fresh Milk Shampoo Made by Variance Concentrations of Surfactant and Co-Surfactant}

\begin{abstract}
A good shampoo, should be able to clean up and have a stable oil-in-water emulsion. It needs variance concentrations between surfactant and co-surfactant combination and also variations in the use of solvents during the development process to find the most ideal combination. This study aim was to obtain the optimum formula and preparation method of fresh milk shampoo. This study was used experimental design by factorial design method. The whole design of the formulas (F1-F9) were sampled and was made with variance concentrations of surfactant (sodium lauryl sulphate) and co-surfactant (cocamide diethanolamide) combination. Shampoo was made using two methods, each method using different solvent during the preparation, namely method $\mathrm{A}$ (aquadest) and $\mathrm{B}(\mathrm{NaCl})$. Each method was applied to make the nine formulas (F1-F9). Observation of the shampoo quality and acceptability was conducted during 60 days. Shampoo parameters were measured variables in this study. The results of this study indicate that $3 \mathrm{~B}$ formula was the optimum formula and preparation method in the first evaluation in physical stability and $\mathrm{pH}$. The $3 \mathrm{~B}$ formula had the most stable emulsion formula among all formulas, with number of pH 6.2. It also had the ability to clean and disperse water into water (44.7\%) and produce soft texture of foam. The 3B formula contains $0.4 \%$ protein, values of viscosity was $670 \mathrm{Cp}$, and did not contain pathogenic fungi and bacteria. The conclusion of this study was the $3 \mathrm{~B}$ formula as the optimum fresh milk shampoo with a combination of $30 \%$ surfactant and $1 \%$ co-surfactant, which was prepared by method $\mathrm{B}$ using $\mathrm{NaCl}$ solution as solvent.
\end{abstract}

Keywords: Co-surfactant, Fresh milk shampoo, Preparation method, Shampoo quality, Surfactant.

\footnotetext{
* Program Studi Farmasi, FKUB $\quad{ }^{* *}$ Laboratorium Farmasi Komunitas, FKUB

*** Laboratorium Farmasetik, FKUB $\quad{ }^{* * * *}$ Laboratorium Farmakognosi, FKUB
} 


\section{PENDAHULUAN}

Rambut merupakan karakteristik seksual sekunder yang sangat penting bagi kaum pria maupun wanita. Penampilan rambut memiliki kontribusi besar terhadap kondisi psikologis seseorang dalam menunjang aktivitas kehidupan. Rambut merupakan salah satu indikator dari kondisi kesehatan secara keseluruhan. Kondisi rambut yang sehat, merupakan cerminan seseorang akan kondisi kesehatan nutrisi, asupan air, dan relaksasi yang memadai. Sebaliknya, apabila nutrisi dan asupan air tidak adekuat, serta tubuh kurang relaksasi, akan menimbulkan efek negatif terhadap rambut, sehingga dapat membuat rambut yang semula sehat, menjadi tidak sehat. ${ }^{1}$ Rambut memiliki dua fungsi utama. Menjaga kulit kepala dari paparan sinar matahari yang berbahaya dan berbagai gesekan ataupun benturan. Selain rambut, terdapat juga sebum, yang pada dasarnya berfungsi sebagai lubrikan yang melindungi kulit kepala dan rambut, agar terjaga kelembabannya. Sebum dihasilkan oleh bagian kulit kepala yang disebut dengan kelenjar sebacea. Akan tetapi, produksi sebum yang kontinyu, menyebabkan sebum berada dalam jumlah berlebihan pada permukaan kulit kepala, sehingga penampilan rambut menjadi tampak berminyak. Selain itu, debu dan kotoran juga dapat melekat pada lapisan sebum, sehingga rambut menjadi tampak kusam. ${ }^{1}$

Penggunaan sampo sebagai pembersih dan sumber nutrisi merupakan solusi dari permasalahan rambut akibat jumlah sebum yang berlebih pada kulit kepala dan nutrisi rambut yang tidak adekuat. Surfactant merupakan kunci dari pembersihan rambut, karena struktur molekulernya yang terdiri dari bagian hidrofilik dan lipofilik, memiliki kemampuan menurunkan tegangan permukaan antara air dan kotoran, sehingga kotoran tersuspensi dalam fase air. ${ }^{2}$ Penelitian terdahulu menunjukkan bahwa formula sampo berbasis protein, mampu menutrisi rambut agar kembali sehat. Sehingga, susu sapi segar adalah bahan yang tepat untuk ditambahkan ke dalam formula sampo sebagai sumber nutrisi untuk rambut. ${ }^{3}$ Komposisi formula sampo terdiri dari bahan utama dan bahan tambahan. Bahan utama terdiri dari surfactant dan cosurfactant sebagai agen surface-active. Bahan tambahan terdiri dari sumber nutrisi, penstabil $\mathrm{pH}$, thickening agent sebagai agen pengontrol viskositas, pengawet untuk stabilisasi produk, fragrance untuk memperkuat karakter produk, dan pelarut? Kriteria sampo yang baik, minimal harus dapat membersihkan, memiliki emulsi minyak dalam air yang stabil, aroma dan warna yang konsisten, viskositas yang baik (kental), $\mathrm{pH}$ mendekati pH fisiologis kulit kepala, menghasilkan busa kecil yang stabil dan melimpah, tidak mengiritasi kulit, dan tidak melampaui batas kontaminasi mikroba. ${ }^{4}$ Salah satu parameter kriteria sampo yang baik adalah busa. Guna memenuhi kriteria tersebut, tidak hanya digunakan surfactant (sodium lauryl sulphate) secara tunggal, tetapi cosurfactant (cocamide diethanolamide) sebagai penunjang surfactant. Sodium lauryl sulphate (surfactant anionik) sering dikombinasikan dengan cocamide diethanolamide (surfactant nonionik) untuk menghasilkan busa yang lebih ideal dan mencegah terjadinya proses penghilangan minyak yang berlebihan dari kulit kepala. ${ }^{5}$ Variasi konsentrasi kombinasi surfactant dan co- surfactant dibutuhkan untuk mencari konsentrasi kombinasi yang paling ideal. Viskositas yang baik (kental) juga menjadi salah satu 
parameter kriteria sampo yang baik. Untuk digunakan satu jenis pelarut (aquades), tetapi pelarut kombinasi (aquades dan sodium chloride), yang diduga lebih optimal dalam meningkatkan viskositas sampo, melalui pembentukan larutan isotonik selama proses pembuatan sampo. ${ }^{5}$ Variasi penggunaan pelarut selama proses pembuatan, dibutuhkan untuk mencari teknik pembuatan sampo yang paling ideal. Oleh karena itu, untuk mencapai spesifikasi kriteria sampo yang memenuhi kriteria tersebut, tidak hanya baik, dibutuhkan optimasi formula dan teknik pembuatan sampo, dengan bahan tambahan berupa susu sapi segar, menggunakan kombinasi surfactant (sodium lauryl sulphate) dan co-surfactant (cocamide diethanolamide). Penelitian ini bertujuan untuk memperoleh formula dan teknik pembuatan sampo yang optimum, menggunakan kombinasi surfactant dan co-surfactant.

\section{BAHAN DAN METODE}

\section{Rancangan Penelitian}

Penelitian ini adalah penelitian eksperimental dengan menggunakan

rancangan penelitian factorial design seperti yang ditampilkan pada Tabel 1.

Tabel 1. Factorial design kombinasi surfactant dan co-surfactant

\begin{tabular}{|c|c|c|c|}
\hline $\begin{array}{c}\text { Factorial } \\
\text { Design }\end{array}$ & $\operatorname{CDE} 1 \%$ & CDE $2 \%$ & CDE $3 \%$ \\
\hline SLS 10\% & $\begin{array}{l}\text { F1 } \\
\text { SLS 10\% } \\
\text { CDE 1\% }\end{array}$ & $\begin{array}{l}\text { F2 } \\
\text { SLS 10\% } \\
\text { CDE 2\% }\end{array}$ & $\begin{array}{l}\text { F3 } \\
\text { SLS 10\% } \\
\text { CDE 3\% }\end{array}$ \\
\hline SLS 20\% & $\begin{array}{l}\text { F4 } \\
\text { SLS 20\% } \\
\text { CDE 1\% }\end{array}$ & $\begin{array}{l}\text { F5 } \\
\text { SLS 20\% } \\
\text { CDE 2\% }\end{array}$ & $\begin{array}{l}\text { F6 } \\
\text { SLS 20\% } \\
\text { CDE 3\% }\end{array}$ \\
\hline SLS 30\% & $\begin{array}{l}\text { F7 } \\
\text { SLS 30\% } \\
\text { CDE } 1 \%\end{array}$ & $\begin{array}{l}\text { F8 } \\
\text { SLS 30\% } \\
\text { CDE 2\% }\end{array}$ & $\begin{array}{l}\text { F9 } \\
\text { SLS 30\% } \\
\text { CDE 3\% }\end{array}$ \\
\hline
\end{tabular}

Keterangan: SLS = sodium lauryl sulphate dan $\mathrm{CDE}=$ cocamide diethanolamide 
masing-masing kelompok pengamatan yang dibuat dengan metode $A$ dan $B$.

\section{Rancangan Formula Sampel \\ Penelitian}

Pada Tabel 2 ditampilkan formula
Metode A menggunakan pelarut aquades, sementara metode $B$ menggunakan aquades dan $\mathrm{NaCl}$.

Tabel 2. Formulasi metode A dan B

\begin{tabular}{|c|c|c|c|c|c|c|c|c|c|}
\hline \multirow{2}{*}{$\begin{array}{l}\text { Nama } \\
\text { Bahan }\end{array}$} & \multicolumn{9}{|c|}{ Konsentrasi Bahan (\%) } \\
\hline & F1 & F2 & F3 & F4 & F5 & F6 & F7 & F8 & F9 \\
\hline SLS & 10 & 10 & 10 & 20 & 20 & 20 & 30 & 30 & 30 \\
\hline $\mathrm{CDE}$ & 1 & 2 & 3 & 1 & 2 & 3 & 1 & 2 & 3 \\
\hline Susu & 10 & 10 & 10 & 10 & 10 & 10 & 10 & 10 & 10 \\
\hline $\begin{array}{l}\text { Asam } \\
\text { Sitrat } \\
\text { Mono } \\
\text { Hidrat }\end{array}$ & 0,015 & 0,015 & 0,015 & 0,015 & 0,015 & 0,015 & 0,015 & 0,015 & 0,015 \\
\hline $\mathrm{NaCl}$ & 6 & 6 & 6 & 6 & 6 & 6 & 6 & 6 & 6 \\
\hline Pewangi & 0,5 & 0,5 & 0,5 & 0,5 & 0,5 & 0,5 & 0,5 & 0,5 & 0,5 \\
\hline $\begin{array}{l}\text { Sodium } \\
\text { Benzoat }\end{array}$ & 0,5 & 0,5 & 0,5 & 0,5 & 0,5 & 0,5 & 0,5 & 0,5 & 0,5 \\
\hline Air & $\begin{array}{l}\text { ad } \\
100\end{array}$ & $\begin{array}{l}\text { ad } \\
100\end{array}$ & $\begin{array}{l}\text { ad } \\
100\end{array}$ & $\begin{array}{l}\text { ad } \\
100\end{array}$ & $\begin{array}{l}\text { ad } \\
100\end{array}$ & $\begin{array}{l}\text { ad } \\
100\end{array}$ & $\begin{array}{l}\mathrm{ad} \\
100\end{array}$ & $\begin{array}{l}\mathrm{ad} \\
100\end{array}$ & $\begin{array}{l}\text { ad } \\
100\end{array}$ \\
\hline
\end{tabular}

Keterangan: SLS = sodium lauryl sulphate dan $\mathrm{CDE}=$ cocamide diethanolamide

\section{Lokasi dan Waktu Penelitian}

Penelitian dilakukan dalam jangka waktu 60 hari. Proses pembuatan dan penyimpanan sampel, serta pengamatan terhadap stabilitas fisik, stabilitas $\mathrm{pH}$, kemampuan membersihkan, dispersi kotoran, dan busa sampel dilakukan di Laboratorium Farmasetika Fakultas Kedokteran Brawijaya. Pengamatan terhadap stabilitas kimia dan viskositas sampel sampo dilakukan di Laboratorium Pengujian Mutu dan Keamanan Pangan Fakultas Teknologi Pertanian Brawijaya. Pengamatan terhadap pertumbuhan jamur dan bakteri pada sampo dilakukan di Laboratorium Mikrobiologi Fakultas Kedokteran Brawijaya dan Instalasi Mikrobiologi Klinik RSUD Dr. Saiful Anwar Malang. 


\section{Prosedur Penelitian}

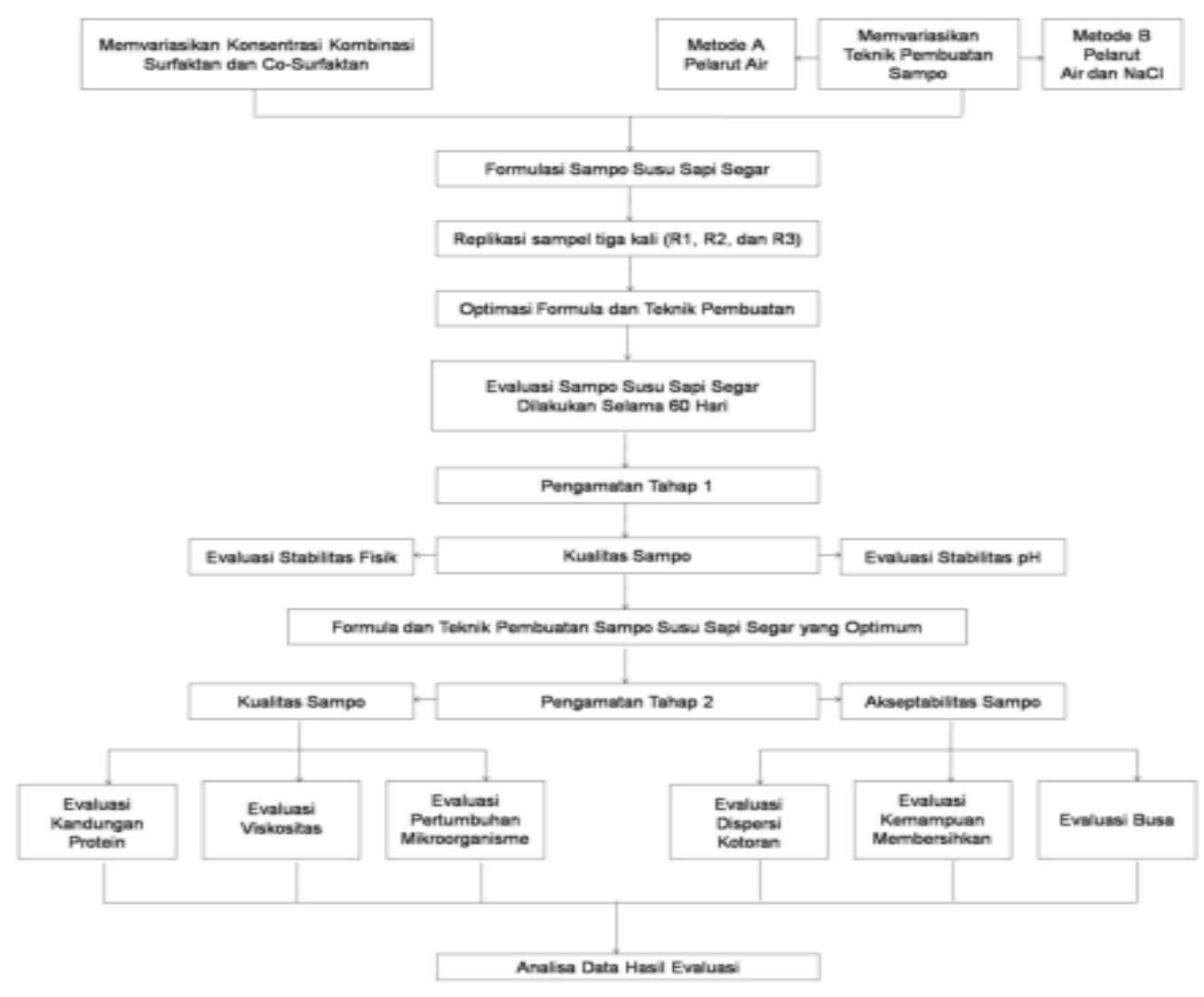

Gambar 1. Prosedur penelitian

\section{Proses Pembuatan Sampo Metode A}

Metode pembuatan sampo untuk volume 1 liter diawali dengan proses pasteurisasi susu sapi segar $100 \mathrm{ml}$ susu didinginkan pada suhu $4{ }^{\circ} \mathrm{C}$. Kemudian dipanaskan hingga suhu 72 ${ }^{\circ} \mathrm{C}$, selama 15 detik. Lalu didinginkan kembali pada suhu $4^{\circ} \mathrm{C}$ dan ditambahkan dengan 5 gram sodium benzoate. Sebanyak $500 \mathrm{ml}$ pelarut (aquades) dipanaskan hingga suhu $100{ }^{\circ} \mathrm{C}$, selama 10 menit, kemudian tuang ke dalam beaker glass kosong, lalu ditutup rapat. Sodium lauryl sulphate ditimbang sebanyak $100 \mathrm{~g}$ untuk $\mathrm{F} 1, \mathrm{~F} 2$, dan F3; sebanyak $200 \mathrm{~g}$ untuk F4, F5, dan F6; dan $300 \mathrm{~g}$ untuk F7, F8, dan F9. SLS dimasukkan ke dalam beaker glass kemudian diaduk menggunakan stirrer hingga mengembang (membentuk busa putih), dengan ditambahkan $200 \mathrm{ml}$ aquades hingga homogen. Kemudian ditambahkan CDE sebanyak $10 \mathrm{ml}$ untuk F1, F4, F7; sebanyak $20 \mathrm{ml}$ untuk F2, F5, F8; sebanyak $30 \mathrm{ml}$ untuk F3, F6, F9. Selanjutnya ditambahkan $0,15 \mathrm{~g}$ asam sitrat yang dilarutkan dalam $50 \mathrm{ml}$ aquades. Lalu ditambahkan susu sapi pasteurisasi sebanyak $100 \mathrm{ml}$. Kemudian ditambahkan $5 \mathrm{ml}$ fragrance dan $60 \mathrm{~g}$ $\mathrm{NaCl}$ yang dilarutkan dalam $250 \mathrm{ml}$ aquades. Kemudian sampo dituangkan ke dalam botol sampel, lalu dilakukan penandaan botol sampel dengan nomer 
rancangan formula (F1-F9) dan metode yang diaplikasikan (A).

\section{Proses Pembuatan Sampo Metode B}

Metode pembuatan sampo untuk volume 1 liter diawali dengan proses pasteurisasi susu sapi segar. Sebanyak $100 \mathrm{ml}$ susu didinginkan pada suhu $4{ }^{\circ} \mathrm{C}$. Kemudian dipanaskan hingga suhu $72{ }^{\circ} \mathrm{C}$, selama 15 detik. Lalu didinginkan kembali pada suhu $4{ }^{\circ} \mathrm{C}$ dan ditambahkan dengan $5 \mathrm{~g}$ sodium benzoate. Sebanyak $500 \mathrm{ml}$ pelarut (aquades) dipanaskan hingga suhu $100{ }^{\circ} \mathrm{C}$, selama 10 menit, kemudian tuang ke dalam beaker glass kosong, lalu ditambahkan $60 \mathrm{~g} \mathrm{NaCl}$. Sodium lauryl sulphate ditimbang sebanyak $100 \mathrm{~g}$ untuk F1, F2, dan F3; sebanyak $200 \mathrm{~g}$ untuk F4, F5, dan F6; dan $300 \mathrm{~g}$ untuk F7, F8, dan F9. SLS dimasukkan ke dalam beaker glass kemudian diaduk menggunakan stirrer hingga mengembang (membentuk busa putih), dengan ditambahkan $200 \mathrm{ml}$ larutan $\mathrm{Nacl}$ hingga homogen. Kemudian ditambahkan CDE sebanyak $10 \mathrm{ml}$ untuk $\mathrm{F} 1$, F4, F7; sebanyak $20 \mathrm{ml}$ untuk F2, F5, F8; sebanyak $30 \mathrm{ml}$ untuk $\mathrm{F} 3, \mathrm{~F} 6, \quad \mathrm{~F} 9$. Selanjutnya ditambahkan $0,15 \mathrm{~g}$ asam sitrat yang dilarutkan dalam $50 \mathrm{ml}$ larutan $\mathrm{NaCl}$. Lalu ditambahkan susu sapi pasteurisasi sebanyak $100 \mathrm{ml}$. Kemudian ditambahkan $5 \mathrm{ml}$ fragrance dan $250 \mathrm{ml}$ larutan $\mathrm{NaCl}$. Kemudian sampo dituangkan ke dalam botol sampel, lalu dilakukan penandaan botol sampel dengan nomer rancangan formula (F1-F9) dan metode yang diaplikasikan (B).

\section{Evaluasi Kualitas Sampo Susu Sapi Segar}

Evaluasi kualitas dilakukan untuk mengetahui performa sampo.

Uji Stabilitas Fisik dan Kimia
Uji stabilitas fisik dilakukan dengan cara identifikasi volume, warna dan stabilitas warna secara visual menggunakan indera penglihatan. Selain itu, stabilitas pewangi diamati menggunakan indera penciuman. Uji stabilitas emulsi juga dilakukan, guna memastikan sediaan tidak mengalami perubahan (seperti creaming, kristalisasi atau presipitasi dari komposisi, dan perubahan warna produk), termasuk homogenitas dan kejernihan, selama penyimpanan. Uji stabilitas kimia dilakukan dengan menguji kandungan protein, dengan menghitung nilai $\mathrm{N}$-total dalam sampo menggunakan metode Kjeldahl.

\section{Uji pH}

Uji $\mathrm{pH}$ dilakukan dengan cara mengukur $\mathrm{pH}$ sampo menggunakan $\mathrm{pH}$ meter. $^{7}$

\section{Uji Viskositas}

Uji viskositas dilakukan dengan menggunakan rotational viscometer tipe spindle L2 kecepatanrotasi $30 \mathrm{rpm}$.

\section{Uji Pertumbuhan Mikroorganisme}

Prosedur identifikasi jamur pada sampel adalah agar $\left(40{ }^{\circ} \mathrm{C}\right) \quad 9,5 \mathrm{ml}$ dicampurkan dengan $0,5 \mathrm{ml}$ sampel sampo, dimasukkan ke medium (plate) SD yang diinkubasi pada suhu $37{ }^{\circ} \mathrm{C}$ selama 24 jam. Kemudian, dilakukan pengamatan terhadap medium SD secara visual. Apabila timbul bercak, maka sampo dapat dikatakan mengandung jamur. Apabila tidak timbul bercak, maka sampo dapat dikatakan tidak mengandung jamur. Identifikasi bakteri pada sampel menggunakan medium NA yang diinkubasi pada suhu $37^{\circ} \mathrm{C}$ selama 24 jam. Kemudian, dilakukan pengamatan terhadap medium NA secara visual. Apabila timbul bercak, maka sampo dapat dikatakan mengandung bakteri. 
Apabila tidak timbul bercak, maka sampo dapat dikatakan tidak mengandung bakteri. Apabila sampel terbaca mengandung bakteri, maka diperlukan identifikasi bakteri lanjutan untuk memastikan bakteri patogen atau non patogen.

\section{Evaluasi Akseptabilitas Sampo}

Evaluasi akseptabilitas dilakukan untuk mengetahui gambaran penerimaan sampo oleh konsumen.

\section{Uji Dispersi Kotoran}

Uji dispersi kotoran dilakukan dengan cara mencampurkan 2 tetes sampo dengan $10 \mathrm{ml}$ aquades, kemudian pada gelas ukur, ditambahkan tinta berwarna merah, kemudian dilakukan pengocokan selama 10 kali. $^{7}$

\section{Uji Kemampuan Membersihkan}

Uji kemampuan membersihkan dilakukan dengan cara menempelkan 0,5 $\mathrm{g}$ adeps lanae (diasumsikan sebagai sebum) ke $5 \mathrm{~g}$ benang wol. Kemudian, benang wol yang telah ditambahkan adeps lanae tersebut, dimasukkan ke dalam botol yang berisi $200 \mathrm{ml}$ air yang mengandung 1 g sampo. Selanjutnya, dilakukan pengocokan selama selang waktu 4 menit (tiap menit dilakukan 50 kali pengocokan). Benang wol ditiriskan, kemudian dikeringkan dengan hair dryer. Sampel yang dikeringkan kemudian ditimbang. Selanjutnya, kemampuan membersihkan dihitung dengan rumus sebagai berikut: ${ }^{7}$

$$
D P=100(1-T / C)
$$

\author{
Keterangan: \\ DP = Detergency Power \\ $\mathrm{T}=$ berat lemak tersisa pada benang wol \\ $\mathrm{C}=$ berat lemak
}

\section{Uji Kemampuan Busa dan Stabilitas \\ Busa}

Uji kemampuan busa dan stabilitas busa dilakukan dengan cara $50 \mathrm{ml}$ larutan sampo $1 \%$ diletakkan pada gelas, kemudian gelas ditutup dengan penutup gelas, dan dikocok 10 kali. Total volume busa diukur setiap 1 menit, selama 4 menit.

\section{HASIL}

\section{Evaluasi terhadap Stabilitas Fisik Sampo}

Penyusutan volume ditemukan pada seluruh formula saat hari ke-8 pengamatan. Namun tidak ditemui adanya penyusutan (volume tetap) pada pengamatan selanjutnya hingga harike-60. Formula yang dibuat dengan metode $A$ mengalami penyusutan volume 41-62 \% dari volume awal. Formula yang dibuat dengan metode $B$ mengalami penyusutan volume $29-43 \%$ dari volume awal. Penyusutan volume tertinggi di antara seluruh rancangan formula (F1-F9) dan teknik pembuatan (metode $\mathrm{A}$ atau $\mathrm{B}$ ) dialami formula $4 \mathrm{~A}$. Penyusutan volume terendah di antara seluruh rancangan formula (F1-F9) dan teknik pembuatan (metode A atau B) dialami formula 3B. Formula 3B merupakan formula optimum, apabila dilihat dari segi penyusutan volume yang dihasilkan (Gambar 2). 


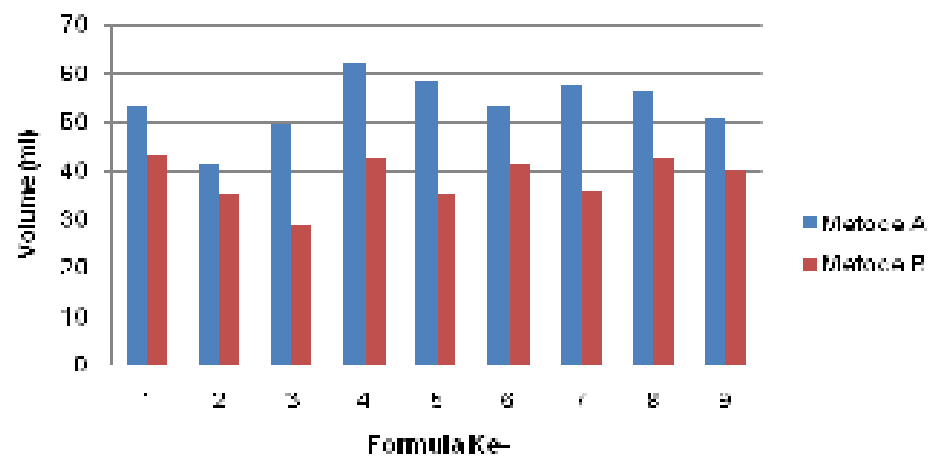

Gambar 2. Penyusutan volume pada formula 1-9 menggunakan metode A dan B.

Pengamatan terhadap aroma seluruh rancangan formula menunjukkan kestabilan aroma dari hari ke-1 hingga hari ke-60 pengamatan, yakni tetap tercium aroma melati. Pengamatan terhadap warna seluruh rancangan formula yang dibuat menunjukkan kestabilan warna dari hari ke-1 hingga hari ke-60 pengamatan, yakni sama dengan sampo di hari ke-8 pengamatan.

Analisis data hasil evaluasi menyimpulkan bahwa aroma dan warna tidak dipengaruhi oleh formulasi dan teknik pembuatan.

Pengamatan terhadap stabilitas emulsi, seluruh rancangan formula stabil, homogen dan memiliki emulsi stabil keruh di hari ke-1 dan ke-8 pengamatan. Sebagian besar formula mengalami ketidakstabilan emulsi berupa creaming sejak hari ke-15 pengamatan. Analisis data hasil evaluasi terhadap stabilitas emulsi secara keseluruhan, menyimpulkan bahwa formula yang dibuat dengan metode B memiliki stabilitas dan homogenitas yang lebih baik jika dibandingkan dengan formula yang dibuat dengan metode A. Sehingga, dapat disimpulkan bahwa formula 3B merupakan formula optimum, apabila dilihat dari segi stabilitas fisik (volume, aroma, dan warna) maupun dari segi stabilitas emulsi sampo yang dihasilkan.

\section{Evaluasi Stabilitas pH Sampo}

Formula yang dibuat dengan metode $A$ mengalami penurunan nilai $\mathrm{pH}$ 14,1-33,8 $\%$ dari $\mathrm{pH}$ awal. Formula yang dibuat dengan metode $\mathrm{B}$ mengalami penurunan nilai $\mathrm{pH} \quad 15-32,9 \%$ dari $\mathrm{pH}$ awal. Penurunan nilai $\mathrm{pH}$ tertinggi dan terendah diantara seluruh rancangan formula dialami formula 9A dan 1A (Gambar 3). Analisis data hasil evaluasi menyimpulkan bahwa formula yang dibuat dengan metode $A$ cenderung mengalami penurunan nilai $\mathrm{pH}$ dibandingkan dengan formula yang dibuat dengan metode $B$. Sehingga dapat disimpulkan bahwa nilai $\mathrm{pH}$ dipengaruhi oleh formulasi, sedangkan teknik pembuatan tidak berpengaruh terhadap $\mathrm{pH}$. 


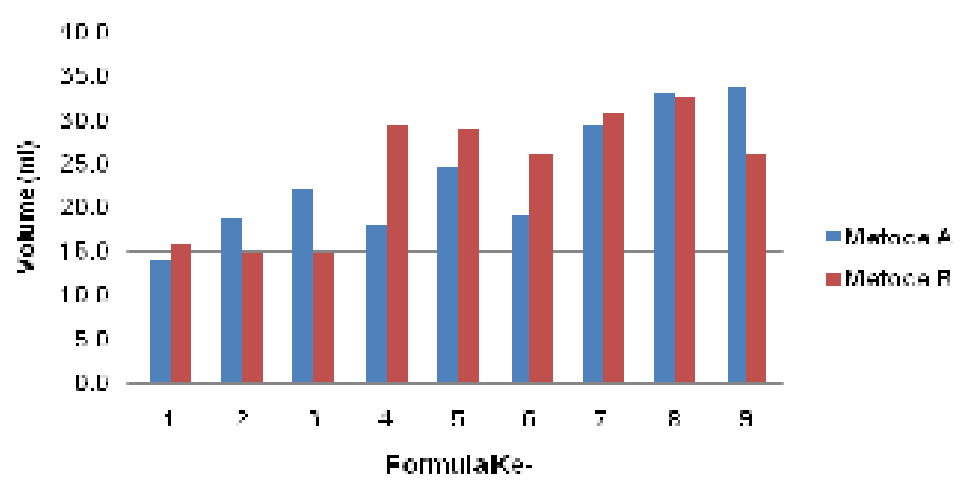

Gambar 3. Penurunan nilai pH pada berbagai formula (F1-F9) menggunakan metode A dan B.

Evaluasi Kemampuan Dispersi Kotoran Sampo

Pengamatan terhadap kemampuan dispersi kotoran seluruh rancangan formula yang dibuat menunjukkan bahwa seluruh formula memiliki kualitas sampo yang baik. Kualitas sampo dibuktikan dengan tinta berwarna merah yang terdispersi dalam larutan sampo, sehingga air berwarna merah, sedangkan busa berwarna putih (Gambar 4). Sehingga, dapat disimpulkan bahwa formula 3B memiliki kemampuan dispersi kotoran yang baik (sesuai kriteria ideal sampo).

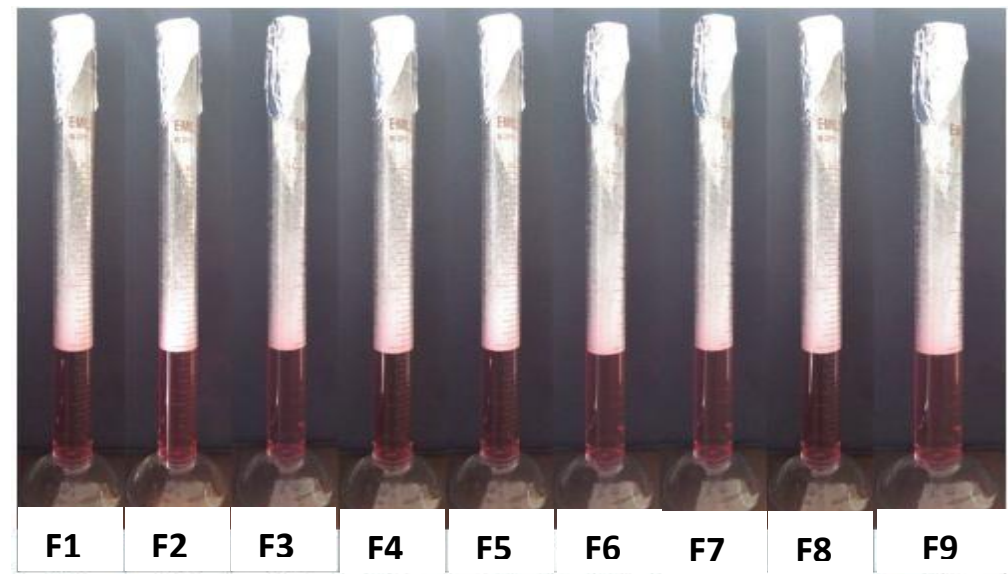

Gambar 4. Kemampuan dispersi kotoran oleh sampo formula 1-9

\section{Evaluasi Kemampuan Membersihkan Sampo}

Pengamatan terhadap kemampuan m embersihkan seluruh rancangan formula yang dibuat menunjukkan bahwa seluruh formula memiliki kemampuan membersihkan yang baik. Formula yang dibuat dengan metode A memiliki kemampuan membersihkan 13,3-56,7 \%. Formula yang dibuat dengan metode $B$ memiliki kemampuan membersihkan 1853,3 \% (Gambar 5). Dapat disimpulkan bahwa formula 3B memiliki kemampuan membersihkan yang baik $(44,7 \%)$. 


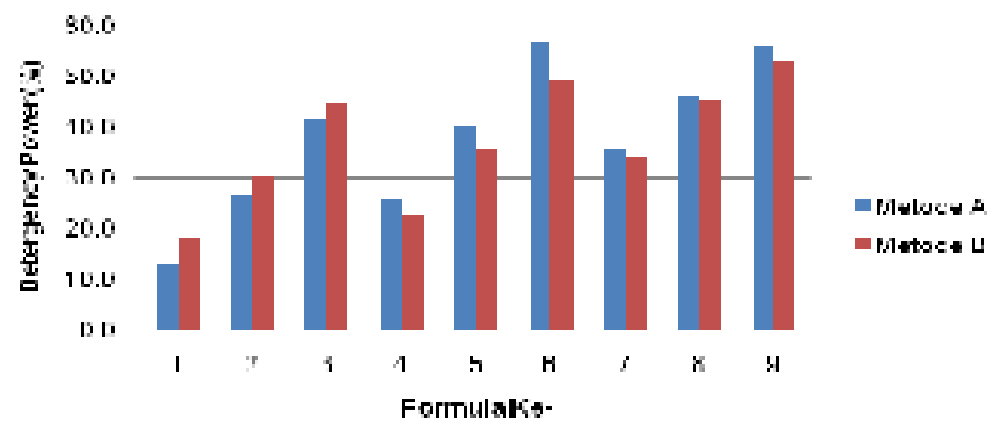

Gambar 5. Kemampuan membersihkan pada formula 1-9 menggunakan metode A dan B.

$\begin{array}{lll}\text { Evaluasi } & \text { Kemampuan } \quad \text { Sampo } & \text { Menghasilkan Busa } \\ \text { Pengamatan terhadap kemampuan } & \text { menghasilkan busa sampo yang baik. } \\ \text { menghasilkan busa dari seluruh rancangan } & \text { Seluruh formula menunjukkan tekstur busa } \\ \text { formula yang dibuat menunjukkan bahwa } & \text { lembut dan variasi kuantitas volume busa } \\ \text { seluruh formula memiliki kemampuan } & \text { (Gambar 6). }\end{array}$

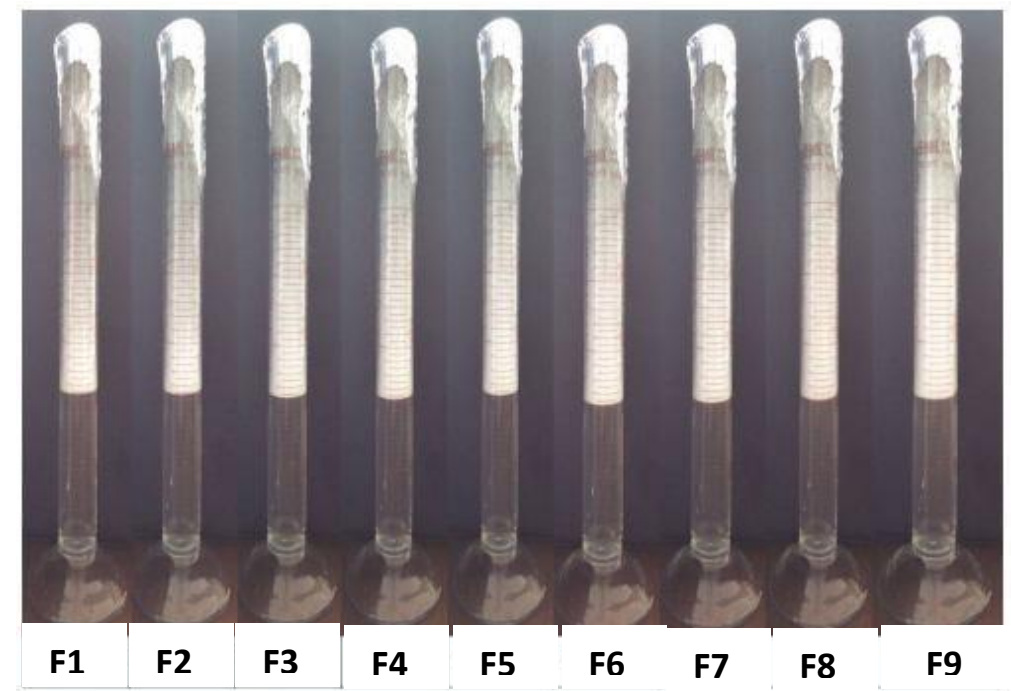

Gambar 6. Kemampuan sampo formula 1-9 dalam menghasilkan busa

Evaluasi Kandungan Protein Sampo Kandungan protein dalam formula $3 \mathrm{~B}$ sebesar $0,3525 \%$, sehingga formula $3 B$ memenuhi kriteria sampo yang ideal dalam menutrisi rambut, karena terbukti memiliki kandungan protein.

\section{Evaluasi Viskositas Sampo}

Hasil pengujian terhadap formula 3B R1, $\mathrm{R} 2$, dan R3 menunjukkan nilai viskositas 696, 691, dan $622 \mathrm{Cp}$, dengan rata-rata nilai viskositas $670 \mathrm{Cp}$. Sehingga, dapat disimpulkan bahwa formula 3B memenuhi kriteria rentan viskositas sampo yang ideal (500-1500 Cp).

\section{Evaluasi Pertumbuhan Mikroorganisme Sampo}

Analisis data hasil evaluasi terhadap pertumbuhan mikroorganisme pada sampo menyimpulkan bahwa formula $3 \mathrm{~B}$ tidak mengandung jamur dan bakteri patogen. Sehingga, dapat disimpulkan bahwa formula 3B memenuhi persyaratan daya tahan mikrobiologi sampo (Gambar 7). 


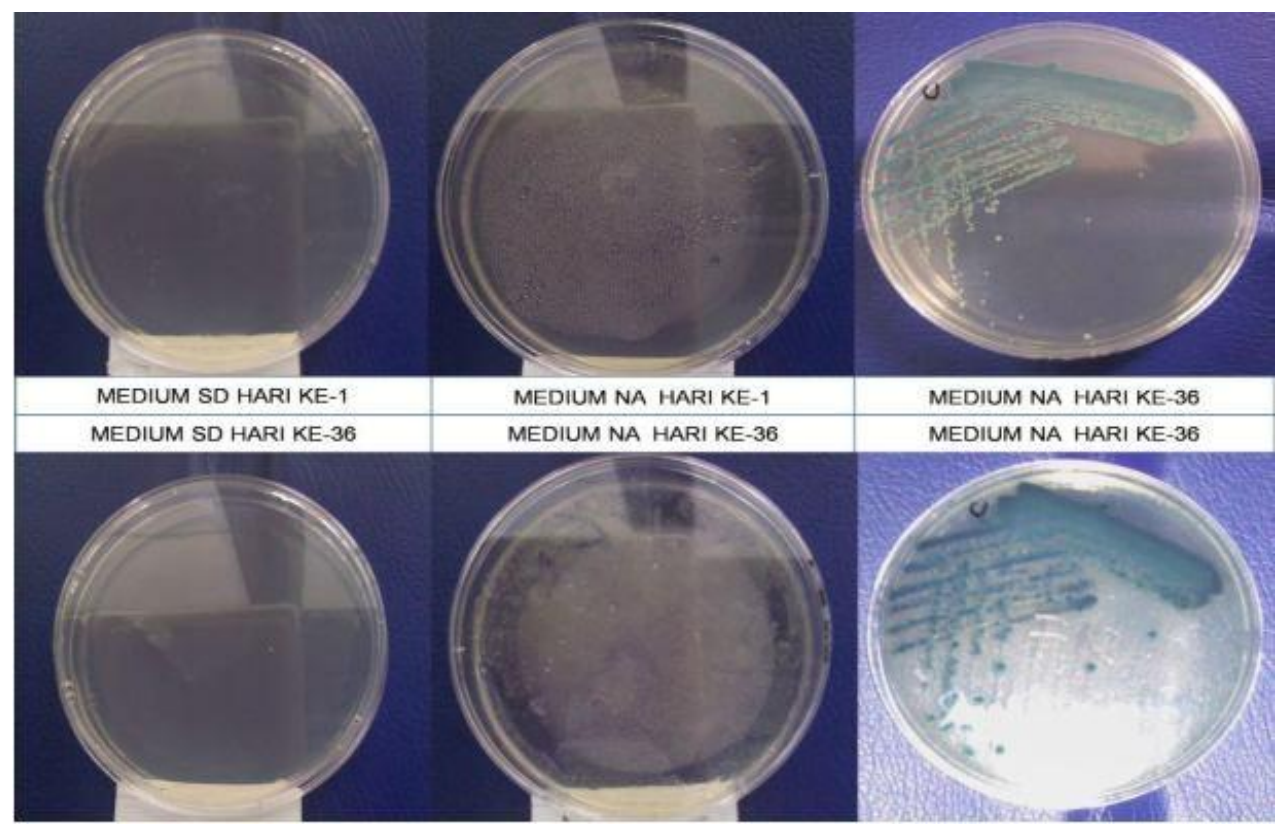

Gambar 7. Deteksi jamur (medium SD) dan bakteri patogen (medium NA) pada sampo hari ke1 dan ke-36

\section{PEMBAHASAN}

Komposisi formula sampo terdiri dari bahan utama dan bahan tambahan. ${ }^{2}$ Seluruh bahan yang digunakan berada dalam rentang konsentrasi yang diperbolehkan dan umum digunakan, serta memenuhi standar keamanan penggunaan oleh manusia. Bahan utama terdiri dari surfactant (sodium lauryl sulphate) dan co- surfactant (cocamide diethanolamide) sebagai surface-active agent. Bahan tambahan terdiri dari sumber nutrisi (susu sapi segar), penstabil $\mathrm{pH}$ (asam sitrat monohidrat), thickening agent (sodium chloride) sebagai agen pengontrol viskositas, pengawet (sodium benzoat) untuk stabilisasi produk, pewangi untuk memperkuat karakter produk, dan aquades. Sodium lauryl sulphate (anionic surfactant) dikombinasikan dengan cocamide diethanolamide (nonionic surfactant) untuk menghasilkan busa yang lebih ideal dan mencegah terjadinya proses penghilangan minyak yang berlebihan dari kulit kepala. ${ }^{5}$ Variasi konsentrasi kombinasi antara surfactant dan co-surfactant dirancang guna menentukan kombinasi yang paling optimum untuk formula sampo. Viskositas yang baik (kental) juga menjadi salah satu parameter kriteria sampo yang baik. ${ }^{6}$ Penerapan dua teknik pembuatan yang berbeda, dengan menggunakan pelarut aquades dan larutan $\mathrm{NaCl}$ selama proses pembuatan dirancang guna menentukan teknik pembuatan yang paling optimum untuk membuat sampo yang ideal.

Sebelum digunakan, seluruh alat dibersihkan terlebih dahulu. Selain itu, pembersihan alat ditujukan untuk meminimalisir kontaminasi mikroba yang dianggap dapat mempengaruhi hasil evaluasiterhadap pertumbuhan mikroorganisme sampo. Preparasi bahan dimulai dengan pasteurisasi susu sapi segar, dengan cara memanaskan susu hingga suhu $72{ }^{\circ} \mathrm{C}$, selama 15 detik, kemudian ditambahkan dengan sodium benzoate. Pasteurisasi dilakukan dengan ketentuan waktu dan temperatur guna menjaga kualitas dan nutrisi dalam susu. ${ }^{9}$ Pasteurisasi dilanjutkan dengan 
penyimpanan susu yang sudah dipasteurisasi dalam wadah tertutup rapat, sebelum digunakan. Selanjutnya, dilakukan pemanasan pelarut (aquades) hingga suhu $100{ }^{\circ} \mathrm{C}$ selama 10 menit, kemudian penimbangan dan pengukuran sesuai rancangan formulasi, serta pencampuran bahan. Pengamatan terdiri dari dua tahap. Tahap satu (uji kualitas) terdiri dari evaluasi terhadap stabilitas fisik dan $\mathrm{pH}$ sampo selama 30 hari. Kemudian, didapatkan formula dan teknik pembuatan sampo susu sapi segar yang optimum. Evaluasi tahap satu merupakan evaluasi yang paling esensial di antara evaluasi yang lain, karena stabilitas fisik dan stabilitas $\mathrm{pH}$ adalah gambaran performa sampo yang paling menentukan penilaian konsumen. Uji stabilitas fisik dan stabilitas $\mathrm{pH}$ sampo, dilakukan setiap tujuh hari guna memastikan sediaan mengalami perubahan atau tidak selama penyimpanan produk. Selain itu, agar peneliti dapat mengetahui trend terkait stabilitas, yang terjadi pada sampel tiap tujuh hari pengamatan. Pengamatan stabilitas fisik sampo, terdiri dari pengamatan organoleptik sampo (volume, aroma, dan warna) dan stabilitas emulsi. Variasi volume yang terbentuk dari seluruh rancangan formula disebabkan oleh penggunaan konsentrasi surfactant (sodium lauryl sulphate) dan co- surfactant (cocamide diethanolamide) yang berbedabeda di setiap formula, sementara volume pelarut yang digunakan tetap. sodium lauryl sulphate memiliki nilai HLB tinggi, sehingga emulsi yang terbentuk adalah emulsi minyak dalam air (o/w). Saat proses pengadukan berlangsung, emulsi yang terbentuk adalah satu fase, berupa emulsi berwarna putih (encer). Emulsi berwarna putih terbentuk oleh kandungan surfactant yang larut dalam pelarut, sehingga menghasilkan busa berwarna putih. Busa putih terbentuk akibat input energi kinetik dari proses pengadukan menggunakan alat stirrer. Saat proses pengadukan dihentikan, perlahan emulsi akan memisah menjadi dua fase, berupa lapisan atas berwarna putih dan lapisan bawah tidak berwarna. Emulsi kembali menjadi satu fase, berupa emulsi tidak berwarna (kental) pada keesokan harinya (hari kedua). Proses pemisahan dari dua fase, kembali menjadi satu fase, terjadi seiring dengan penyusutan volume, yang menghasilkan peningkatan viskositas. Oleh karena itu, pada hari ke-8 pengamatan ditemukan penyusutan volume sampo. Penyusutan volume tertinggi diantara seluruh rancangan formula (F1-F9) dan teknik pembuatan (metode $A$ atau $B$ ) ditemukan pada formula 4A (62 \%). Penyusutan volume terendah diantara seluruh rancangan formula (F1-F9) dan teknik pembuatan (metode $\mathrm{A}$ atau $\mathrm{B}$ ) ditemukan pada formula $3 B(29 \%)$. Formula $3 B$ merupakan formula optimum, apabila dilihat dari segi penyusutan volume yang dihasilkan. Penyusutan volume menghasilkan peningkatan viskositas dari yang semula encer menjadi kental. Dapat diartikan bahwa pelarut yang digunakan selama proses pembuatan sampo, mempengaruhi pembentukan volume sampo. Hal tersebut disebabkan oleh karena metode $\mathrm{B}$ menggunakan pelarut berupa larutan $\mathrm{NaCl}$. Elektrolit yang dihasilkan oleh larutan $\mathrm{NaCl}$, digunakan untuk meningkatkan viskositas sampo melalui perannya sebagai regulator viskositas. ${ }^{6}$ Mekanisme pengentalan oleh larutan $\mathrm{NaCl}$ adalah dengan memodifikasi struktur misel. ${ }^{10}$ Misel surfactant bergabung dengan agen pengental hidrofobik. Saat agen hidrofilik mengecil, agen hidrofilik mengubah bentuk misel yang semula spheric (berbentuk bola) menjadi rod-like (berbentuk batang). Pada fase istirahat, misel bergerak secara acak, 
sehingga meningkatkan viskositas. ${ }^{10}$ Sehingga dapat disimpulkan bahwa teknik pembuatan sampo dengan menggunakan metode B lebih optimum dibandingkan dengan teknik pembuatan menggunakan metode A, karena menghasilkan penyusutan volume yang lebih rendah dibandingkan formula yang dibuat dengan metode A. Selanjutnya adalah pengamatan terhadap stabilitas emulsi. Emulsi dikatakan stabil apabila tidak mengalami creaming, sedimentasi, flokulasi dan koalesen. Secara umum, seluruh rancangan formula stabil, homogen dan memiliki emulsi berwarna keruh pada hari ke-1 dan ke-8 pengamatan. Hal tersebut dikarenakan kekuatan dan pembentukan interfacial film berhasil membentuk stabilitas emulsi selama tujuh hari penyimpanan produk. Formula 3B, 5B, 6B, 8B dan 9B merupakan formula optimum, ditinjau dari segi stabilitas emulsi yang dihasilkan, karena tidak mengalami creaming dari awal hingga akhir pengamatan. Seluruh rancangan formula (kecuali formula $8 \mathrm{~A}$, $3 \mathrm{~B}, 5 \mathrm{~B}, 6 \mathrm{~B}, 8 \mathrm{~B}$, dan 9B) mengalami ketidakstabilan emulsi berupa creaming sejak hari ke-15 pengamatan. Creaming yang timbul bervariasi pada masingmasing formula. Formula $2 \mathrm{~A}, 3 \mathrm{~A}$, dan $5 \mathrm{~A}$ mengalami creaming di bagian permukaan botol. Creaming yang terjadi di permukaan botol sampel dapat disebabkan oleh berat jenis minyak yang kurang dari air. Formula $6 \mathrm{~A}, 7 \mathrm{~A}, 8 \mathrm{~A}, 9 \mathrm{~A}$, dan 2B mengalami creaming di bagian dasar botol. Creaming yang terjadi di dasar botol sampel, dapat disebabkan oleh penggumpalan akibat fermentasi laktosa yang terkandung dalam susu sapi segar menjadi asam laktat, sehingga menimbulkan penggumpalan kasein yang ditunjukkan endapan putih pada dasar botol. Formula 1A, 4A, 1B, 4B, dan 7B mengalami creaming di bagian permukaan dan dasar botol. Creaming yang terjadi di permukaan dan dasar botol sampel, dapat disebabkan oleh kedua faktor (berat jenis dan penggumpalan) yang terjadi secara bersamaan. Meskipun demikian, berdasarkan hasil pengamatan, seluruh rancangan formula sampo yang mengalami creaming, akan homogen kembali seperti semula apabila dilakukan pengocokan sederhana. Hal tersebut dapat disebabkan oleh droplet emulsi sampo yang tetap dilingkupi dengan film pelindung. ${ }^{11}$ Data pengamatan terhadap ketidakstabilan emulsi sampo membutuhkan data pendukung berupa data pengamatan terhadap kejernihan sampo. Penetapan kriteria ideal kejernihan sampo memerlukan studi yang lebih dalam. Sehingga, batasan penelitian kejernihan sampo dikatakan memenuhi kriteria ideal selama kejernihan sampo bersifat stabil dari awal hingga akhir pengamatan (stabil keruh atau stabil jernih). Formula 2A, 3A, dan $3 B$ merupakan formula optimum, apabila dilihat dari segi stabilitas kejernihan sampo yang dihasilkan karena stabil keruh dari awal hingga akhir pengamatan.

Data pengamatan terhadap ketidakstabilan emulsi sampo juga membutuhkan data pendukung berupa data pengamatan terhadap homogenitas sampo. Formula 3B, 8B, dan 9B merupakan formula optimum, apabila dilihat dari segi homogenitas yang dihasilkan, karena stabil homogen dari awal hingga akhir pengamatan. Sehingga, dapat disimpulkan bahwa formula 3B merupakan formula optimum, apabila dilihat dari segi stabilitas fisik (volume, aroma, dan warna) maupun dari segi stabilitas emulsi sampo yang dihasilkan.

Berdasarkan data pengamatan ketidakstabilan emulsi sampo berupa creaming selalu diiringi dengan tidak homogennya emulsi dan berubahnya stabilitas kejernihan sampo dari yang 
awalnya keruh menjadi jernih. Emulsi sampo yang keruh dapat mengalami creaming atau tidak. Emulsi sampo yang tidak mengalami creaming dapat bersifat homogen atau tidak. Selanjutnya, evaluasi terhadap stabilitas fisik dan $\mathrm{pH}$ sampo, tetap dilakukan terhadap seluruh formula (F1-F9) untuk memastikan bahwa hasil evaluasi tahap satu tetap konsisten hingga 60 hari pengamatan. Sebagian besar sampo diformulasikan untuk memiliki $\mathrm{pH}$ antara 6,5-8,5. Tidak seluruh formula memenuhi kriteria tersebut. Hanya formula 1A, 2A, 3A, 4A, 5A, 6A, 1B, 2B, 3B, dan $9 B$ yang memenuhi kriteria $(\mathrm{pH} 7,3-8,3)$ pada $\mathrm{pH}$ awal (pengamatan hari ke-1). Sementara formula yang lainnya memiliki $\mathrm{pH}$ di atas 8,5. Sampo yang memiliki pH di atas 8,5 akan lebih mudah menyebabkan iritasi mata, dibandingkan sampo yang memiliki rentang $\mathrm{pH} 6,5-8,5$. Formula yang pada pengamatan hari ke- 60 memenuhi kriteria $\mathrm{pH}$ sampo $(\mathrm{pH} 6,47-6,83)$ adalah formula 2A, 4A, 6A, 7A, dan 8A. Sementara itu, formula yang lainnya memiliki pH 6,1-6,4. Nilai pH 6,1-6,4 sebenarnya tidak menjadi masalah selama nilai $\mathrm{pH}$ berada di atas $\mathrm{pH} 6$. Peneliti menetapkan kriteria ideal $\mathrm{pH} 6,5$ sebagai batas minimal, karena berdasarkan literatur $\mathrm{pH}$ 6-,6,4 berpotensi menimbulkan rasa kasar pada tangan. Akan tetapi, berdasarkan hasil pengamatan, formula yang memiliki nilai $\mathrm{pH} \mathrm{6,1-6,4} \mathrm{dalam}$ penelitian ini tidak dirasakan kasar pada tangan. Seluruh formula mengalami penurunan nilai $\mathrm{pH}$ di hari ke-1 hingga ke-60 pengamatan. Penurunan nilai $\mathrm{pH}$ tertinggi di antara seluruh rancangan formula (F1-F9) dan teknik pembuatan (metode $\mathrm{A}$ atau B) dialami formula 9A. Penurunan nilai $\mathrm{pH}$ terendah di antara seluruh rancangan formula (F1-F9) dan teknik pembuatan (metode $\mathrm{A}$ atau $\mathrm{B}$ ) dialami formula 1A. Hal tersebut dapat disebabkan oleh aktivitas mikroorganisme kandungan susu dalam sampo, antara lain ditandai dengan pengasaman dan penggumpalan akibat fermentasi laktosa menjadi asam laktat. ${ }^{12}$ Selain itu, penurunan $\mathrm{pH}$ dapat disebabkan oleh ketidakstabilan dan tidak homogennya emulsi. Adapun faktor yang mempengaruhi nilai $\mathrm{pH}$ adalah penggunaan susu sebagai bahan tambahan, asam sitrat monohidrat sebagai regulator pengaturan $\mathrm{pH}$ sampo, dan teknik pembuatan sampo. Dapat disimpulkan bahwa nilai $\mathrm{pH}$ dipengaruhi oleh formulasi, sedangkan teknik pembuatan tidak terlalu berpengaruh terhadap $\mathrm{pH}$, karena formula yang dibuat dengan metode $\mathrm{A}$ cenderung mengalami penurunan nilai $\mathrm{pH}$ yang sama dibandingkan dengan formula yang dibuat dengan metode $B$.

Setelah didapatkan formula 3B sebagai formula dan teknik pembuatan sampo yang optimum dari pengamatan tahap satu, dilanjutkan pengamatan tahap dua terhadap formula 3B. Pengamatan tahap dua terdiri dari uji akseptabilitas, yaitu evaluasi terhadap kemampuan dispersi kotoran, kemampuan membersihkan, dan kemampuan sampo dalam menghasilkan busa dan stabilitas busa, serta uji kualitas, yaitu evaluasi terhadap kandungan protein pada sampo, viskositas sampo, dan pertumbuhan mikroorganisme.

Uji akseptabilitas dilakukan pada akhir bulan kedua pengamatan. Hasil pengamatan yang didapatkan di waktu tersebut, merupakan cerminan kondisi pada bulan sebelumnya. Hal tersebut bertujuan agar peneliti dapat memastikan gambaran penerimaan sampo oleh konsumen selama dua bulan pengamatan dengan cara yang praktis dan efektif untuk menarik kesimpulan umum. Uji akseptabilitas tetap dilakukan terhadap seluruh formula (F1-F9) sebagai pembanding hasil evaluasi terhadap 
fomula 3B.

Produksi sebum yang kontinyu setiap harinya menyebabkan rambut tampak berminyak. Selain itu, debu dan kotoran juga dapat melekat pada lapisan sebum, sehingga rambut menjadi tampak kusam. ${ }^{4}$ Hal ini melatarbelakangi evaluasi terhadap kemampuan dispersi kotoran dan kemampuan membersihkan untuk mengetahui kemampuan sampo dalam mengangkat kotoran yang menempel pada kulit kepala dan kemampuan sampo dalam membersihkan sebum yang berlebih pada kulit kepala. Hasil pengamatan terhadap kemampuan dispersi kotoran menyimpulkan bahwa formula 3B memiliki kualitas sampo yang baik, yaitu dibuktikan dengan tinta berwarna merah yang terdispersi dalam larutan sampo, sehingga air berwarna merah, sedangkan busa berwarna putih. Sampo berkualitas merupakan pertanda sampo mudah dibilas dan mampu mendispersi kotoran sehingga terlarut dalam air. ${ }^{13}$

Hasil pengamatan dilanjutkan pada kemampuan sampo untuk membersihkan. Lemak bulu domba (Adeps lanae) dipilih sebagai perumpamaan sebum dalam pelaksanaan evaluasi kemampuan membersihkan, karena komposisinya sebagai lemak hewani, dianggap mendekati komposisi sebum. Sementara itu, benang wol digunakan sebagai perumpamaan rambut. Penelitian

sebelumnya mengemukakan bahwa detergency power sampo umumnya berada dalam rentang 18-33\%.13 Akan tetapi, dijelaskan pula bahwa tidak ada persentase yang ditetapkan sebagai persyaratan uji kemampuan membersihkan yang baik. Sehingga, dapat disimpulkan bahwa kemampuan membersihkan semakin baik apabila mendekati nilai $100 \%$. Berdasarkan hasil pengamatan, formula yang dibuat dengan metode $A$ dan $B$ memiliki rentang kemampuan membersihkan (detergency power) sebesar 13,3-56,7 \% dan 18-53,3 $\%$. Meski demikian, persentase tersebut tidak berhasil mencapai 100 \%. Hal tersebut karena sifat bahan adeps lanae yang licin, menyerupai lilin, dan tidak larut dalam air, sehingga sukar untuk dibersihkan. Selain itu, dalam evaluasi tersebut, kadar lemak yang digunakan 0,5 $\mathrm{g}$, sementara sampo yang digunakan hanya $1 \mathrm{~g}$, yang dilarutkan dalam $200 \mathrm{ml}$ air. Sehingga, dengan tingkat kesulitan pembersihan adeps lanae yang dianggap lebih besar dari sebum, dapat disimpulkan bahwa kemampuan membersihkan formula 3B sebesar 44,7 \% adalah optimum, karena memiliki kualitas kemampuan membersihkan di atas ratarata (18-33 \%). Kemampuan membersihkan meningkat seiring dengan peningkatan konsentrasi surfactant dan co-surfactant yang digunakan dalam setiap formula dan dipengaruhi oleh teknik pembuatan. Formula yang dibuat dengan metode $A$, umumnya memiliki kemampuan membersihkan yang lebih tinggi jika dibandingkan dengan formula yang dibuat dengan metode $B$.

Konsumen umumnya menilai kemampuan membersihkan suatu sampo melalui busa yang dihasilkan. Aroma busa dan tekstur busa lembut yang membuat busa dirasakan di tangan seperti krim, merupakan hasil dari pengamatan terhadap seluruh formula sampo yang dibuat dengan metode $\mathrm{A}$ dan $\mathrm{B}$. Volume busa yang dihasilkan juga menjadi penilaian dalam uji kemampuan busa. Volume busa diukur dengan cara mengukur volume busa yang terbentuk setiap menit, selama empat menit, setelah pengocokan sebanyak sepuluh kali, botol yang berisi $50 \mathrm{ml}$ larutan sampo $1 \%$. Volume busa yang dihasilkan seluruh formula bervariasi. Berdasarkan hasil pengamatan, formula yang dibuat dengan 
metode A dan B menghasilkan volume busa 44,3-83,3 $\mathrm{ml}$ dan 48,3-67,5 ml. Dapat disimpulkan bahwa kemampuan menghasilkan busa formula 3B sebesar $54,3 \mathrm{ml}$ adalah optimum, karena memiliki volume busa lebih dari $100 \%$ (100\% adalah $50 \mathrm{ml}$ volume larutan sampo). ${ }^{14}$ Ketahanan busa semakin diperkuat, apabila viskositas semakin tinggi. ${ }^{11}$ Busa akan kehilangan stabilitasnya apabila lamellae mengalami kebocoran. ${ }^{4}$ Pada kondisi viskositas yang baik (kental) misel surfactant bergabung dengan agen pengental hidrofobik, sehingga dapat mendukung busa agar tetap terjaga stabilitasnya. ${ }^{10} \mathrm{Hal}$ tersebut yang menjadi protein) dapat diketahui dengan cara mengalikan nilai $\mathrm{N}$-total dengan 6,25 (faktor konversi Metode Kjeldahl). Sehingga, kandungan protein dalam sampo sebesar 0,3525 \%. Sampo terbukti memenuhi kriteria sebagai sampo berbasis protein, karena kandungan protein susu sapi segar formula 3B 0,3525 $\%$. Penelitian terdahulu menunjukkan bahwa formula sampo berbasis protein, mampu menutrisi rambut agar kembali sehat. $^{3}$ Sehingga, dapat disimpulkan bahwa susu sapi segar memang terbukti sebagai bahan yang tepat, untuk ditambahkan ke dalam formula sampo sebagai sumber nutrisi untuk rambut.

Pengamatan tahap dua diakhiri dengan melakukan evaluasi terhadap latar belakang mengapa evaluasi terhadap nilai viskositas sampo harus dilakukan. Hasil pengujian terhadap formula 3B menunjukkan nilai viskositas $670 \mathrm{Cp}$. Dapat disimpulkan bahwa formula 3B memenuhi kriteria rentang viskositas sampo yang ideal (500-1500 Cp).

Evaluasi terhadap kandungan protein sampo bertujuan untuk membuktikan bahwa protein susu sapi segar tetap ada meskipun dijadikan sebagai bahan tambahan dalam formula sampo. Penelitian terhadap kandungan protein formula 3B dilakukan dengan mencari jumlah N-total dalam sampo yaitu 0,0564 $\%$. Kandungan protein kasar (crude pertumbuhan mikroorganisme sampo formula 3B. Produk kosmetik tidak diperbolehkan mengandung mikroorganisme patogen seperti Staphylococcus aureus, Pseudomonas aeruginosa, Candida albicans, bakteri E.coli maupun golongan Enterobacteriaceae lainnya. ${ }^{14}$ Hasil evaluasi terhadap pertumbuhan mikroorganisme pada sampo menyimpulkan bahwa formula $3 \mathrm{~B}$ tidak mengandung jamur dan bakteri patogen, sehingga memenuhi persyaratan daya tahan mikrobiologi sampo. Pada Tabel 3 ditampilkan rekapitulasi hasil pengamatan yang dilakukan terhadap seluruh rancangan formula (F1-F9) yang dibuat dengan metode $A$ dan $B$. 
Tabel 3. Rekapitulasi hasil pengamatan seluruh rancangan formula (F1-F9)

\begin{tabular}{|c|c|c|c|c|c|c|c|c|c|c|c|}
\hline \multirow{4}{*}{ Ranking } & \multirow{2}{*}{\multicolumn{5}{|c|}{$\begin{array}{c}\text { Evaluasi Tahap I } \\
\text { Kualitas }\end{array}$}} & \multicolumn{6}{|c|}{ Evaluasi Tahap II } \\
\hline & & & & & & \multicolumn{3}{|c|}{ Akseptabilitas } & \multicolumn{3}{|c|}{ Kualitas } \\
\hline & \multicolumn{4}{|c|}{ Stabilitas Fisik } & \multirow[b]{2}{*}{$\begin{array}{c}\text { Stabilitas } \\
\mathrm{pH}\end{array}$} & \multirow[b]{2}{*}{$\begin{array}{l}\text { Dispersi } \\
\text { Kotoran }\end{array}$} & \multirow[b]{2}{*}{$\begin{array}{l}\text { Kemampuan } \\
\text { Membersihkan }\end{array}$} & \multirow[b]{2}{*}{$\begin{array}{l}\text { Volume } \\
\text { Busa }\end{array}$} & \multirow[b]{2}{*}{ Viskositas } & \multirow[b]{2}{*}{$\begin{array}{c}\text { Kandungan } \\
\text { Protein }\end{array}$} & \multirow[b]{2}{*}{$\begin{array}{l}\text { Kontrol } \\
\text { Mikroba }\end{array}$} \\
\hline & V & Aroma & Warna & $\begin{array}{c}\text { Stabilitas } \\
\text { Emulsi }\end{array}$ & & & & & & & \\
\hline 1 & $3 B$ & $1 A$ & $1 \mathrm{~A}$ & 38 & $1 \mathrm{~A}$ & $1 \mathrm{~A}$ & $6 A$ & $6 \mathrm{~A}$ & $3 B$ & 38 & $3 B$ \\
\hline 2 & $5 B$ & $2 A$ & $2 A$ & $5 B$ & $3 B$ & $2 A$ & $9 \mathrm{~A}$ & $7 \mathrm{~A}$ & & & \\
\hline 3 & $2 B$ & $3 A$ & $3 A$ & $6 B$ & $2 B$ & $3 A$ & 98 & $1 \mathrm{~A}$ & & & \\
\hline 4 & $7 \mathrm{~B}$ & $4 A$ & $4 \mathrm{~A}$ & 88 & $1 \mathrm{~B}$ & $4 \mathrm{~A}$ & 68 & $8 \mathrm{~B}$ & & & \\
\hline 5 & $9 \mathrm{~B}$ & $5 A$ & $5 A$ & $9 B$ & $4 \mathrm{~A}$ & $5 A$ & $8 \mathrm{~A}$ & $1 \mathrm{~B}$ & & & \\
\hline 6 & $2 \mathrm{~A}$ & $6 \mathrm{~A}$ & $6 A$ & $3 A$ & $2 A$ & $6 A$ & $8 B$ & $9 A$ & & & \\
\hline 7 & $6 \mathrm{~B}$ & $7 \mathrm{~A}$ & $7 \mathrm{~A}$ & $8 A$ & $6 \mathrm{~A}$ & $7 \mathrm{~A}$ & $3 B$ & $8 \mathrm{~A}$ & & & \\
\hline 8 & $8 B$ & $8 A$ & $8 \mathrm{~A}$ & $2 B$ & $3 A$ & $8 A$ & $3 A$ & $7 \mathrm{~B}$ & & & \\
\hline 9 & $4 B$ & $9 A$ & $9 \mathrm{~A}$ & $6 \mathrm{~A}$ & $5 A$ & $9 A$ & $5 A$ & $5 B$ & & & \\
\hline 10 & $1 \mathrm{~B}$ & $1 \mathrm{~B}$ & $1 \mathrm{~B}$ & $9 \mathrm{~A}$ & $9 \mathrm{~B}$ & $1 \mathrm{~B}$ & $7 \mathrm{~A}$ & $2 A$ & & & \\
\hline 11 & $3 A$ & $2 B$ & $2 B$ & $1 \mathrm{~A}$ & $6 \mathrm{~B}$ & $2 B$ & $5 B$ & $9 \mathrm{~B}$ & & & \\
\hline 12 & $9 \mathrm{~A}$ & $3 B$ & 3B & $2 A$ & $5 B$ & $3 B$ & $7 \mathrm{~B}$ & $2 \mathrm{~B}$ & & & \\
\hline 13 & $6 \mathrm{~A}$ & $4 B$ & $4 B$ & $5 A$ & $4 \mathrm{~B}$ & AB & $2 B$ & $3 B$ & & & \\
\hline 14 & $1 \mathrm{~A}$ & $5 B$ & $5 B$ & $4 \mathrm{~A}$ & $7 \mathrm{~A}$ & $5 B$ & $2 A$ & $6 \mathrm{~B}$ & & & \\
\hline 15 & $8 \mathrm{~A}$ & $6 B$ & $6 B$ & $7 \mathrm{~A}$ & $7 \mathrm{~B}$ & $6 \mathrm{~B}$ & $4 A$ & $5 A$ & & & \\
\hline 16 & $7 \mathrm{~A}$ & 78 & 78 & $1 \mathrm{~B}$ & $8 B$ & 78 & $4 B$ & $3 A$ & & & \\
\hline 17 & $5 A$ & $8 B$ & $8 B$ & $4 B$ & $8 A$ & $8 B$ & $1 \mathrm{~B}$ & $4 B$ & & & \\
\hline 18 & $4 A$ & $9 B$ & 98 & $7 \mathrm{~B}$ & $9 A$ & $9 B$ & $1 \mathrm{~A}$ & $4 A$ & & & \\
\hline Keterangan T & Tabel: & $\square$ & $\begin{array}{l}\text { Posisi } \\
\text { Tidak }\end{array}$ & $\begin{array}{l}\text { Teratas (Pali } \\
\text { Dilakukan } \mathrm{Pa}\end{array}$ & $\begin{array}{l}\text { ing Ideal) } \\
\text { ida Formula Se }\end{array}$ & in $3 B$ & $\longrightarrow$ Posisi Fo & rmula 38 & & Posisi Selur & \\
\hline
\end{tabular}




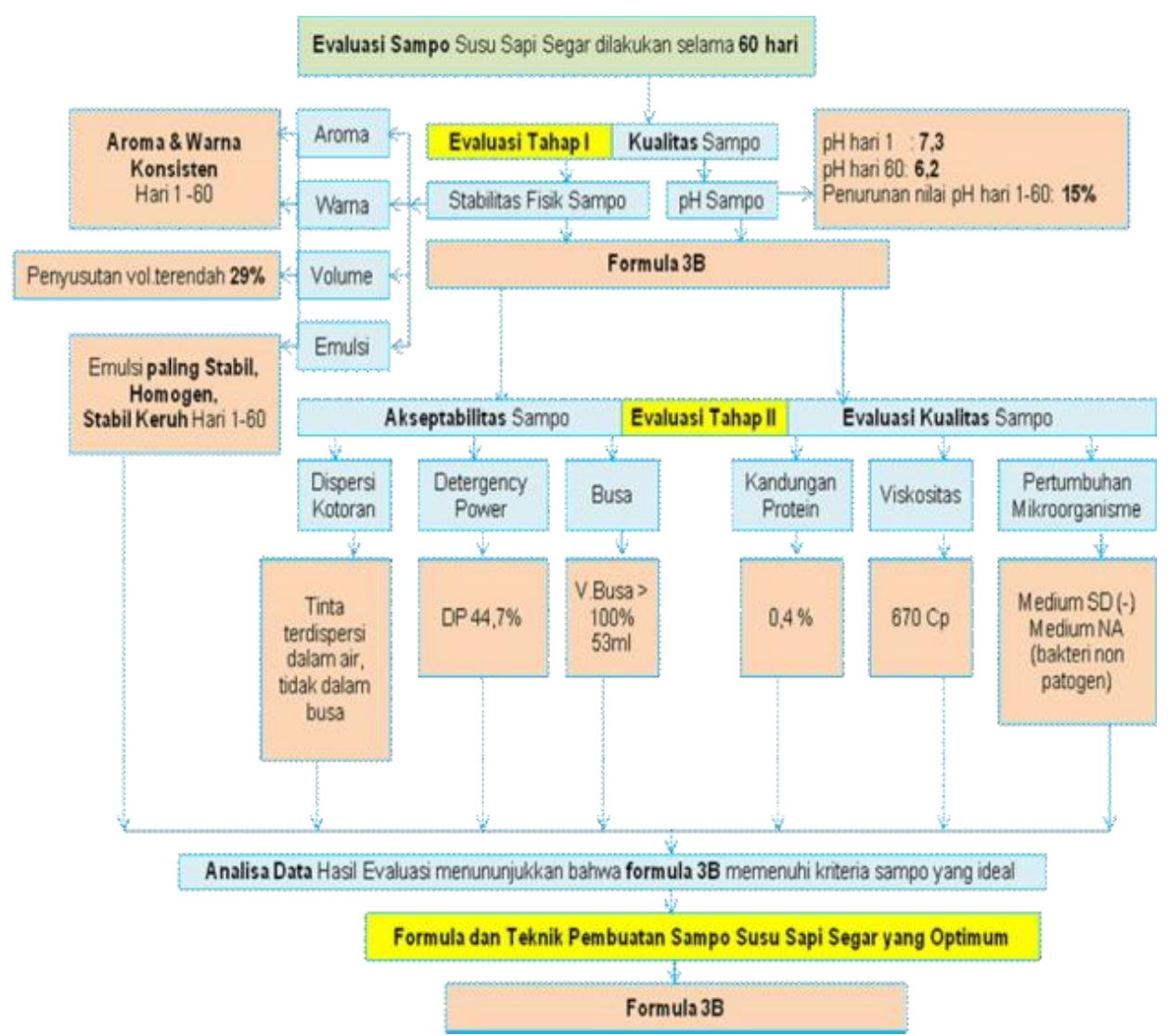

Gambar 8. Rekapitulasi hasil pengamatan formula 3B

Berdasarkan uraian di atas, dapat disimpulkan bahwa formula sampo susu sapi segar 3B telah memenuhi kriteria sampo yang diinginkan di era modern. Terbuat dari bahan yang aman (tidak toksik dan menimbulkan iritasi), mengandung protein untuk menutrisi rambut (nilai protein $0,4 \%$ ) memiliki aroma dan warna yang konsisten, emulsi minyak dalam air yang stabil, $\mathrm{pH}$ mendekati $\mathrm{pH}$ fisiologis kulit kepala ( $\mathrm{pH} \mathrm{6,2),} \mathrm{viskositas}$ yang kental (670 Cp), tidak melampaui batas kontaminasi mikroba (tidak mengandung jamur dan bakteri patogen) yang mencerminkan daya tahan

\section{KESIMPULAN}

1. Formula optimum sampo susu sapi segar adalah formula sampo 3B, yang menggunakan kombinasi surfactant 30 $\%$ dan co-surfactant $1 \%$ dengan mikrobiologi sampo, memiliki kemampuan dispersi kotoran (mudah dibilas dengan air) dan kemampuan membersihkan (44,7\%) yang baik, serta menghasilkan busa yang lembut. Formula 3B merupakan formula sampo yang optimum, di antara seluruh rancangan formula sampo yang dibuat (Gambar 8). Dapat diartikan bahwa konsentrasi kombinasi surfactant $30 \%$ dan co-surfactant $1 \%$, serta penerapan metode $\mathrm{B}$, yang menggunakan pelarut berupa larutan $\mathrm{NaCl}$ selama proses pembuatan sampo adalah kombinasi yang paling ideal.

menggunakan metode $B$.

2. Teknik pembuatan sampo susu sapi segar menggunakan pelarut berupa larutan $\mathrm{NaCl}$ selama proses pembuatan sampo adalah teknik pembuatan yang 
optimum.

\section{SARAN}

1. Optimasi sebaiknya tetap dilanjutkan pada bulan selanjutnya untuk memperoleh data optimasi yang semakin lengkap.

2. Evaluasi stabilitas emulsi dipercepat dapat dilakukan menggunakan teknik manipulasi temperatur untuk mendapatkan cerminan stabilitas sampo dalam jangka waktu yang lebih lama, dibandingkan pengamatan stabilitas secaramanual.

3. Evaluasi keamanan sebaiknya dilakukan sebagai evaluasi lanjutan untuk memperkuat data optimasi formula dan teknik pembuatan yang telah dilakukan.

\section{DAFTAR PUSTAKA}

1. Hull R. Anatomy and Phisiology for Beauty and Complementary Therapies. Cambridge: The Guild of Beauty Therapists. 2009. p 57-74.

2. Trueb RM. Shampoos: Ingredients, Efficacy, and Adverse Effects. Berlin: Blackwell Verlag. 2007. p 1-10.

3. Araujo R, et al. Biology of Human Hair: Know Your Hair to Control It. Berlin: Springer-Verlag Heidelberg. 2010. p 223.

4. Lochhead RY. Practical Modern Hair Science. Washington: Allured Pub Corp. 2012. p 75-110.

5. Lathauwer G, et al. Thickening of Foaming Cosmetic Formulations. German: $6^{\text {th }}$ World Surfactant Congress CESIO. 2004. p 1-9.
6. Rowe RC. Handbook of Pharmaceutical Excipients Monograph. $5^{\text {th }}$ Edition. London: RPS Publishing. 2006. p 181-637.

7. Sharma RM, et al. Evaluation of Prepared Herbal Shampoo Formulations and to Compare Formulated Shampoo with Marketed Shampoos. International Journal of Pharmacy and Pharmaceutical Sciences. 2011; 39(1):1-4

8. Marczyk G, et al. Essentials of Research Design and Methodology. New Jersey: John Wiley and Sons, Inc. 2005. p 14-16.

9. Brock C, et al. Milk Pasteurization. Michigan: Furthering Families Michigan State University. 2000. p 1-5.

10. Kortemeier U, et al. Thickening Agents for Surfactant Systems. SOFW Journal. 2010. p1-8.

11. Mollet $\mathrm{H}$, et al. Formulation Technology Emulsions, Suspensions, Solid Forms. Jerman: Wiley-VCH. 2004. p 59- 344.

12. Raikos V. Effect of Heat Treatment on Milk Protein Functionality at Emulsion Interfaces: A Review. Greece: Elsevier. 2010. $p$ 1-7.

13. Deshmukh $\mathrm{S}$, et al. Formulations and Evaluation of Herbal Shampoo and Comparative Studies with Herbal Marketed Shampoo. Int J Pharm Bio Sciences. 2012; 3(3):1-9.

14. DHI. Enviromental Project No.1336: Guidance Document on Microbiological Control of Cosmetic Products 20072009. Denmark: Danish Ministry of the Environment, Environmental Protection Agency. 2010. p 13-31. 